\title{
BLACK AND WHITE GIVIL RELIGION AS IDEOLOGY
}

\author{
M. Elaine Botha, \\ Department of Philosophy, PU for CHE
}

ABSTRACT

The author points out that the term ideology has changed to a negative connotation following the initially positive connolation it had. The negative connotation has been reinforced following its association with Marxism. In this article it is pointed out that ideology has increasingly gained the nature of civil religion because soteriological issues have come to be settled in terms of some immanent frame of reference. The author looks at White (Afrikaner) civil religion in South Africa as well as at Black civil religion. The conclusion is inevitably drawn that in both Black and White civil religion in South Africa the fundamental message of the Gospel has been identified with the suffering, oppression or nationalistic aspirations of some or other specific group. The author concludes by saying that to the extent that Afrikaners have done this in the process of history their experience of history ought to be subjected to a critical test in the light of Scriplure. To the extent that Blacks are tempted to harness the fundamental message of the Gospel to their own cullural and national aspiralions, the same test has to be applied.

\section{IDEOLOGY: A PATHOLOGICAL PHENOMENON?}

Etymology

The concept of ideology was a positive one for the French ideologues who coined the term and had in mind a science of ideas which would provide cerlain knowledge based on observation and liberated from religious presuppositions. The concept acquired its negative connotation after Napolcon attacked this group and accused them of being other-wordly and impractical. This negative connotation was also emphasized by Marxism, at a later stage, to signify all ideas not conducive to Marxism, or characteristic of false consciousness. The concept also initially had a strong link with action-orientated ideas propagating political change. 'The negative cannotation of this concept seems to have diminished to such an extent that the term is now used in a variety of connotations ranging from philosophical ideas on the one hand through political ideals to pathological convictions designated as "myths". In spite of this the term is often used in a pejorative sense to designate the system of beliefs contradictory to one's system of belief.

The term can thus be used in a neutral, positive or pcjorative sense. Instead

$48(4) 1983$ 


\section{Black and white}

of using the term ideology in a total sense to include a diversity of topics such as epistemological ideas, ethical notions, religious convinctions, political ideals etc., it is argued here that it ought to be seen as secularized religion and as such it is regarded as a pathological or negative phenomenon.

\section{IDEOLOGY: SECULARIZED RELIGION}

Religion is defined as the focus on and relationship to that which is regarded to be ultimate (Olthius, 19 ). Belief in something which provides ultimate certainty in human life is constitutive of being human. In religion the ultimate questions of human life such as the purpose and meaning of individual and collective life, the goals of living, etc. are dealt with. It includes a confession as to what is the ultimate ground of human and societal existence and leads to a lifestyle or modes of action that are a response to what is regarded as ultimate. It also implies commitment and unconditional surrender to that which is believed to be ultimate. Religion comes to expression in a worldview which embodies a set of values and norms that guide human and societal life and action and which functions as a interpretative framework by which order or disorder is ascertained in reality. Divergent worldviews develop because men put their faith in different absolutes chosen either from immanent reality or from that which is regarded to be transcendent of reality. A religious or confessional vision, as an overall view or perspective on life, arises from and is the outcome of the universal human need to believe in something, to attain certainty, meaning and purpose and as such it reflects and expresses the total personal surrender and commitment of an individual and group. All kinds of ideas or entities can provide such a certitudinal anchor of foundation for a worldview and can therefore function in a religious manner. What is common to both religion and its substitute or secularization, ideology, is the fact that they harbour soteriological convictions concerning the origin, meaning and future of human life, the meaning of suflering, the origin of evil, the possibilities of liberation and redemption (Goudzwaard, n.d.)

Any conviction, ideal, belief or idea which has been proclaimed an absolute acquires an ideological character when it is set apart as an ultimate goal to be achieved at all costs and with the use of all possible means. The power which such an idcology acquires over the lives of individuals and communities leads to the conviction that it will provide and guarantee welfare, properity and progress and that it can claim allegiance from those who believe in its powers, and that it legitimizes any deviation from norms, because it is believed. From the aforementioned argument it is clear that 
structurally there is no difference between religion (either authentic or in its primitive guise) and its substitute, ideology, except the fact that in the case of authentic religion the ultimate point of reference is transcendent and the content of its soteriology is not localized in reality itself, but is given through revelation. In ideology, soteriological issues are settled in terms of some immanent frame of reference. Civil religion represents such an ideology.

\section{CIVIL RELIGION: INTRINSICALLY IDEOLOGICAL?}

Since Bellah's (1967) introduction of the term "civil religion" into the analysis of American culture, it has become an explanatory and analytical tool for a great diversity of political, national and cultural phenomena. As Bellah pointed out in his original essay, his own use of the term "civil religion" was not original but a borrowing from J.J. Rousseau (1967) who used this term to signify the type of national religion which will be able to unify a state and provide the bond of social cohesion which, he argues, is needed for the existence of the state, amidst the dissension and conflict caused by the existence of a variety of religious convictions. Bellah's analysis of the "American way of life" has become the paradigm for other analyses of this phenomenon in other cultural settings. This controversy surfaced in the South African cultural setting approximately in 1975 with the publication of Moodic's The rise of Afrikanerdom in which he traces the roots and structure of Afrikaner civil religion in South Africa. Others soon followed in his stead. Where Moodie defined civil religion with respect to the Afrikanernation as "the religious dimension of the state", it differed from Bellah's view. Bellah did not define it as the worship of the state, but as the inevitable selfunderstanding of the American people (Villa Vicencio, 1977:p. 11).

It is argued here that both Bellah's approach and Moodie's analysis terms of the thesis of civil religion, are inadequate to understand the true nature of civil religion in general and Afrikaner civil religion or Black civil religion specifically. Not all self-understanding of a people is per definition idcological by nature and not all interpretation of the political dimensions of culture in terms of religious insights or convictions constitute a distortion or deviation of true or authentic religiosity. The crucial issue in this respect is the recognition of the fact that cultural or national selfunderstanding acquires ideological overtones when it starts functioning in a religious manner. The mere presence of religious themes such as suffering, rebirth, destiny, calling, etc. might be indicative of the presence of civil religion traits, but need not necessarily point to ideological elements. 


\section{Black and white}

What is needed is a very careful analysis of the manner in which certain ideals and convictions function within the political system or the culture of a group. Civil religion becomes a reality once some or other political or social (cultural or other) ideal provides a basis of certitude and social cohesion, to such an extent that it becomes an ultimate goal with its concomitant absolute values and norms that are subservient to this ultimate goal. The important point is to clearly distinguish between legitimate group cohesion and unity with its symbols and rituals and values and ideologically derailed group cohesio with its ideologically inflated symbols and rituals. The national flag and national anthem of a country are not per definition symbols of the civil religion, but can become such symbols once they function within an ideological frame of reference in which the nation or the state is endowed with ultimate value. This implies that civil religion is intrinsically ideological because it inevitably elevates some social or political ideal or state of affairs to that which is ultimate. It does not, on the other hand, imply that national, political or cultural ideals with their variety of symbols, necessarily represent ideology.

\section{WHITE (AFRIKANER) GIVIL RELIGION IN SOUTH AFRICA}

The analysis of Afrikaner nationalism in South Africa since the introduction of Bellah's concept of civil religion, has very seldom been understood or explained by non- $A$ frikaans-reading authors in any other sense than only as an ideological distortion. The standard procedure by means of which such a conclusion is reached is an analysis of Afrikaner history with special reference to the presence of so-called "civil religious" themes such as eg. the calling of the Afrikaner people, the promised Land (to be reached by the Great Trek), the religious self-understanding which especially becomes apparent in the interpretation of the historical events at Blond River, the emphasis on so-called creation ordinance which would imply that the "volk" or national or cultural group is called to preservation of its identity, etc. This type of analysis can only be refuted once it is recognized that civil religion entails more than the mere identification of such themes.

I would like to argue that alt hough these themes could refer to possible traits of civil religion in the Bellah and Moodie sense of the term, the actual charcter of Afrikaner civil religion ought to be sought elsewhere. I would also like to argue that Afrikaner nationalism as such does not necessarily represent ideological nationalism, but harbours elements of an ideological distortion which ought to be distinguished from authentic and legitimate nationalism. Let me develop the first argument. When looking at some of 
the historical roots of Afrikaner nationalism it is soon clear the it drew from various historical and cultural and philosophical sources and roots, one of which could be called Dutch Calvinism. Central to this notion of Calvinism was the confession of the fact that faith and religious convictions necessarily would lead to an antithesis between believer and unbeliever within the nation or culture - an idea which very soon became part and parcel of the Afrikaner/heritage. This meant that the nation or state or culture could not be declared ultimate, because what was ultimate was the decisive faith in God which relativized all other temporary certitudes and relationships. Within such an appraoch the variety of group relationships such as nation, people and culture had a legitimate place with the understanding that the antithesis between the believer and the unbeliever relativized all of these relationships. Unfortunately this notion of the antithesis was never historically part of Afrikaner culture. A different one was. Gradually the notion of Christian nationalism developed in which the idea of the antithesis reveals a very subtle shift of emphasis. It becomes universalized in the sense that it now divides two national or cultural groups from one another. The imperialistic oppression by the British is now identified with evil; redemption is liberation from the oppression of the political yoke and the "enemy" is now a national enemy. What had been applicable to the church as God's people now is transferred to the nation as such and very subtly an identification takes place between God's cause, which is ultimate, and the national cause, which is relative. In this process both the developments in the realm of party politics and the development of the schools were instrumental. The cultural configuration with which the researcher is now confronted is the fact that the central notion of a people or "volk" has been elevated to a central ideological goal and has acquired ultimate value. Yet not all manifestations of patriotism and nationalism can be subsumed under this disqualifying epithet. When the legitimate allegiance to nation, state or people is relativized by an ultimate allegiance to God it has a legitimate role to play. The consequence of the abovementioned distorted concept of the antithesis led to the development of a public sphere which, although it is called Christian, takes its cues from national ideals and symbols, and a private sphere in which personal religious beliefs are tolerated. Pietism with its emphasis on personal salvation and its lack of emphasis on societal involvement of the Christian, was instrumental in the creation of this dichotomy between the public and private realms. This public realm, constituted by the nation-state and predominantly identified with the cause of the Afrikaner people was christened "Christian-national". 


\section{Black and white}

\section{BLACK GIVII, RELIGION}

The same pietism had also been instrumental in the development of Black civil religion. From its first confrontation with white Christianity in Southern Africa, Black culture has been confronted with a message directed at separating personal religious convictions and politics "by keeping a heavenly peace concerning the critical function of the Christian vis-à-vis politics" (Boessak, 1977:p. 38). Black Christian culture became a curious mixture of "safe" reformed truths and a strange pietistic "other-worldreligiosity" which made it practically impossible to be involved in political issues as Christians. The response within the Black community to their own situation led to the gradual development of what has come to be known as "Black consciousness", with its concomitant variant of liberation theology, called Black Theology.

The question arises as to whether this phenomenon can also be seen as an instance of civil religion in the sense defined above. I would want to argue positively. The literature provides one with a diversity of theoretically formulated positions attempting to explain the relationship between religion and Black culture and nationalism.

The American Black liberation theologian, Cleage, propagated a Black theology which is a justification for what could be called Black Christian nationalism. In this theology Black nationalistic ideals are decisive and Cleage tries to make out a case for a conception of the Messiah as a Black person who came for the liberation of the Black peoples. Here we have religious notions clad in the guise of nationalistic ideals and functioning in a religious, i.e. ideological, manner. Religious notions are interpreted in terms of Black national and cultural aspirations. Such an attempt could of course only represent a distorted hermeneutics. It acquires its ideological overtones the moment it also functions in a religious manner by imbuing Black cultural and national life with ultimate soteriological qualities.

The second position - that of Manas Buthelezi (unpublished paper, 1974, referred to by Boessak, 1977) simply argues that the current experience of the Blacks in Southern Africa is fundamentally the same experience which the Afrikaner culture historically experienced and therefore represents a type of inverse "Afrikaner Christian nationalism" with of course the same possible civil religious overtones. This position has merit. In some sense one is dealing with a second or perhaps evern third generation ideology here. Blacks reacting idealogically over and against Afrikaner - Christian 
national ideology which in turn was a reaction against British imperialism.

The third position - that of Boessak - is harder to deal with. He argues that Christianity cannot be appropriated by any nationalistic group or cause; that Black Theology is a contextual theology which must not yield to critical accommodation becoming a cultural theology or a religion of culture (Boessak, 1977:p. 43). It is exactly the content of this concept of "contextualization" of the Christian religion which ultimately opens the door for the notion of civil religion in the Bellah-sense of the terms, to make it's appearance in Boessak's thought. Although the presence of the themes of exodus, suffering, calling etc. are presented as part and parcel of his Black (liberation) theology I would like to argue that it need of course yet necessarily be signs of the presence of civil religion. When he suddenly adds the claim that only through the political liberation of the Blacks, can the Whites now too become liberated, I discern a soteriological quality being ascribed to the Black political experience. My argument now is that not the mere presence of so-called "civil religion" notions signifies the presence of civil religion, even if they are indicative of the "religious" self-understanding of a people, but they become ideological when ultimacy is ascribed to some aspect of this self-understanding. This I regard to be present the moment when Boessak argues that one particular, relative type of context (the "Black" experience) is proclaimed the epitome of ultimate (political) liberation also for other cultural groups. This I regard as an unmistakeable ideological - and therefore also civil religious - trend. The "Black experience" acquires a soteriological function, it is ascribed a redeeming quality.

\section{DEMYTHOLOGY: THE ONLY ROUTE}

The only adequate route to demythologizing the abovementioned forms of ideology is the critical evaluation of these phenomena through the application of a concept of religion on the one hand and ideology on the other hand, which acknowledges the latter as a negative or distorted instance of the former. This provides criteria by means of which civil religion can be judged as instances of religion, but then qualified as ideological distortions of this phenomenon. The criterion here is the fact that the moment any relative aspect of human life and human existence is given ullimacy it acquires a "religious" significance and when this replaces the Ultimate, God, it becomes ideology.

In the case of Afrikaner civil religion a common denominator type of 
Christianity permeating the public national sphere gradually acquired an ultimate character. It became identified with the national ideals and aspirations of an ethnic and cultural group and universalized to such an extent that the Biblical notion of the antithesis between believer and unbeliever within the one nation or cultural group, was replaced by the antithesis between the members of the Afrikaner people on the one hand and the opposing, oppressive group, the British, on the other hand. Evil, the "enemy", sin, redemption, all acquire nationalistic and cultural overtones in this process and this leads to a religious sanctioning of the most fundamental convictions of the Afrikaner people.

Boessak's version of Black liberation theology with its emphasis on contextualization deliberately and consciously wants to steer clear of the above-mentioned temptation. Yet, it does not succeed in this endeavour. It, in turn, proclaims the Black (political) experience to be the mediating and liberating experience which will also in the long run liberate Whites in South Africa. It could be argued that characterizing Boessak's position as "civil religion" does not recognize the significance of Black cultural consciousness and awakening which has just as legitimate a place as Afrikaner patriotism and Nationalism. He has to be given credit for the fact that he is conscious of the dangers of these phenomena. Yet, ascribing a liberating, mediating and conditional function to Black liberation contradicts his very basic assumption, viz, that the Gospel cannot be appropriated by any specific group for its own nationalistic or cultural ideals. The important issue of contextualization still remains to be dealt with. It is quite true that sin, evil, brokenness and salvation are facts of human life. It is also true that Christ's incarnation has to be acknowledged and $\mathrm{His}$ reconciliation thought through in a myriad of concrete and contextual human life situations. This implies that suffering and oppression are issues that can and ought to be dealt with from the perspective that the Scriptures provide us with, just as national solidarity and cultural individuality are phenomena that ought to be judged and evaluated in the light of Scripture. But this is a far cry from identifying the fundamental message of the Gospel with the suffering, oppression or nationalistic aspirations of some or other group. To the extent that Afrikaners have done this in the process of history their experience of history ought to be subjected to a critical test in the light of Scripture. To the extent that Blacks are tempted to harness the fundamental message of the Gospel to their own cultural and national aspirations, the same test has to be applied. 


\section{BIBLIOGRAPHY}

BELLAH, ROBERT N. 1967. Civil religion in America. Daedalus. Journal of the American Academy of Arts and Sciences, Winter.

BOESSAK, A. 1977. Civil religion and the Black community. Journal of Theology for Southern Africa, no. 19, June, 35-44.

GOUDZWAARD, B. No date. Genoodzaakt goed te wezen. Christelijke hoop in een bezeten wereld. Kampen, Kok.

MOODIE, T. Dunbar, 1975. The rise of Afrikanerdom. Power, apartheid and the Afrikaner civil religion. University of California Press.

OLTHIUS, J.H. 1978. Visions of life and ways of life. The nature of religion. (In: Toward a Biblical view of man. I.C.S. Toronto.)

ROUSSEAU, J.J. 1967. The social contract and discourses on the origin of inequality, by Lester G. Crocker. New York: Pocket Books, book IV, ch. 8, pp. 136-147.

VILLA VICENCIO, G. 1977. South African civil religion: An introduction. Journal of Theology for Southern Africa, no. 19, June, pp. 5-15. 